\title{
Synthesis of spiro-cyclics via ring-closing metathesis
}

\author{
Sambasivarao Kotha* and Ethirajan Manivannan \\ Department of Chemistry, Indian Institute of Technology-Bombay, \\ Powai, Mumbai 400076, India. Fax +91-22-2572 3480 \\ E-mailsrk@chem.iitb.ac.in
}

\section{This paper is dedicated to Dr. Sukh Dev on the occasion of his $80^{\text {th }}$ Birthday}

(received 30 Dec 02; accepted 31 Jan 03; published on the web 15 Feb 03)

\begin{abstract}
Various spiro-cyclic systems were synthesized by utilizing ring-closing metathesis as a key step. The required dialkylated starting materials were prepared from various 1,3-diketones or substrates containing an active methylene group.
\end{abstract}

Keywords: Spirocycles, metathesis, allylation, indane derivatives

\section{Introduction}

Spiro-cyclic compounds have attracted the attention of organic chemists due to their unique structural and reactivity pattern. Many natural products such as fredericamycin $\mathbf{1}^{1}$ (Figure 1), spirovetivanes, acroanes, chamigrenes, ${ }^{2}$ angularly fused cyclopentanoids (e.g. crinipellin-A, laurenene $)^{3}$ and spirocaracolitone $\mathrm{A}^{4}$ have shown to posses spiro-linkage as a structural element. ${ }^{5}$ Among non-natural products [5.5.5.5]fenestrane $3,{ }^{6}$ spiranes, ${ }^{7}$ and coronane 4 posses the spiro-linkage ${ }^{8 a, b}$ as a crucial unit.

Various approaches to prepare spiro-cyclics have encountered problems associated with functional group incompatibility at one or more stages and restricted to a single substitution pattern. In only a few instances, was the newly generated ring system left with a useful functionality for further transformations. Therefore, there is a need to develop new methods for the preparation of the spiro-linkage under milder reaction conditions with additional functionality for further synthetic manipulation. Herein, we report the full details of our methodology for the preparation of spiro-cyclic compounds using ring-closing metathesis (RCM) as a key step. ${ }^{8 c}$ 


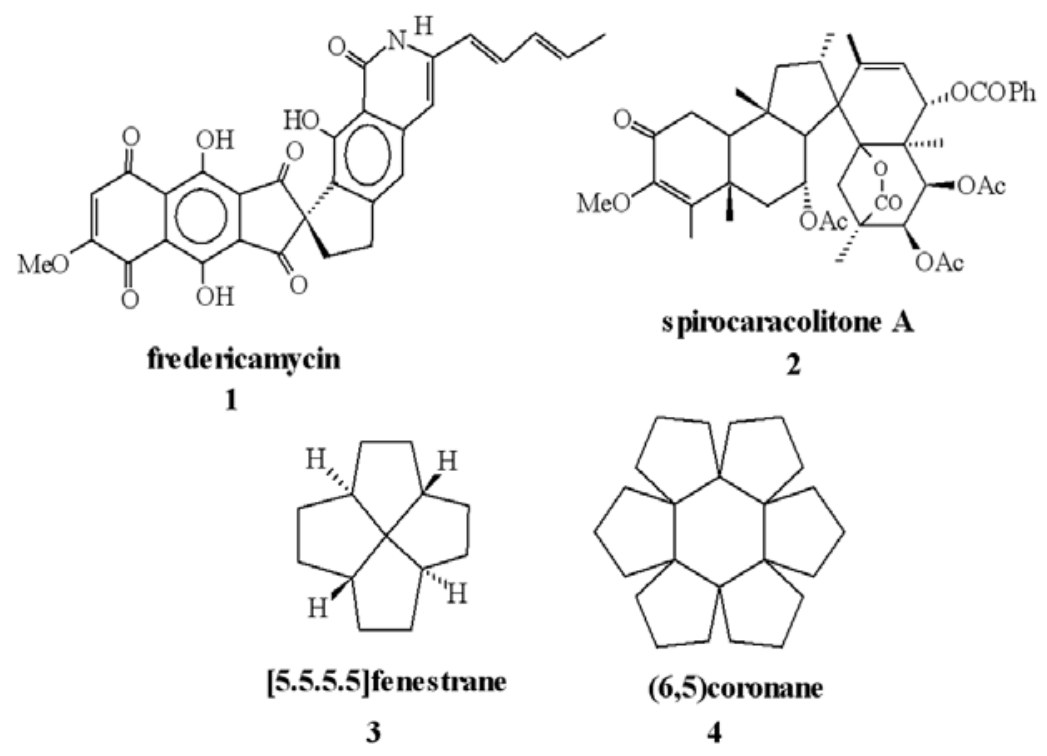

Figure 1

\section{Results and Discussion}

In order to demonstrate the spiro-annulation shown in equation 1 our immediate task was to prepare diallylated compounds. In this regard, we have chosen commercially available 1,3diketones such as dimedone, 1,3-cyclohexanedione, 1,3-cyclopentanedione $\mathbf{5}$ and 1,3indanedione $\mathbf{6}$ and compounds containing an active methylene group (e.g. fluorene 7 and anthrone 8) as our substrates.

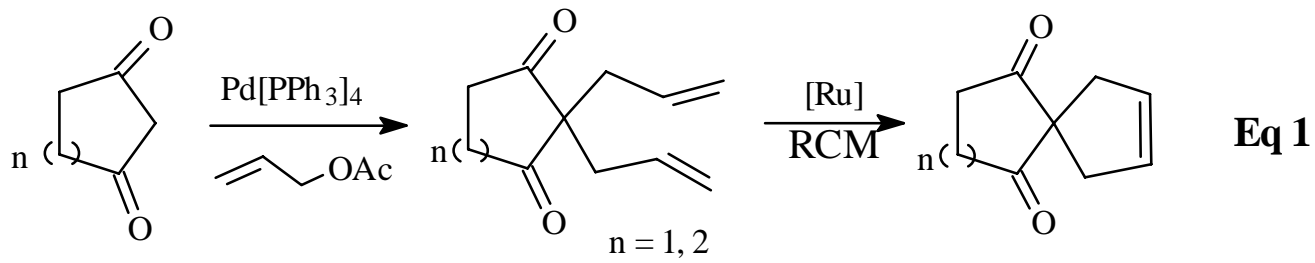

Although several methods are available in the literature for diallylation of active methylene compounds, 1,3-diketones pose a special problem because of unwanted O-alkylation. In this regard, Lapintskaya and Pivnitskii reported ${ }^{9}$ a novel method for C-alkylation of cyclic-diketones by allyl acetate in a weakly acidic medium with $\mathrm{Pd}\left(\mathrm{PPh}_{3}\right)_{4}$ as a catalyst. ${ }^{10}$ This method allows the preparation of the mono- and diallylated products. 

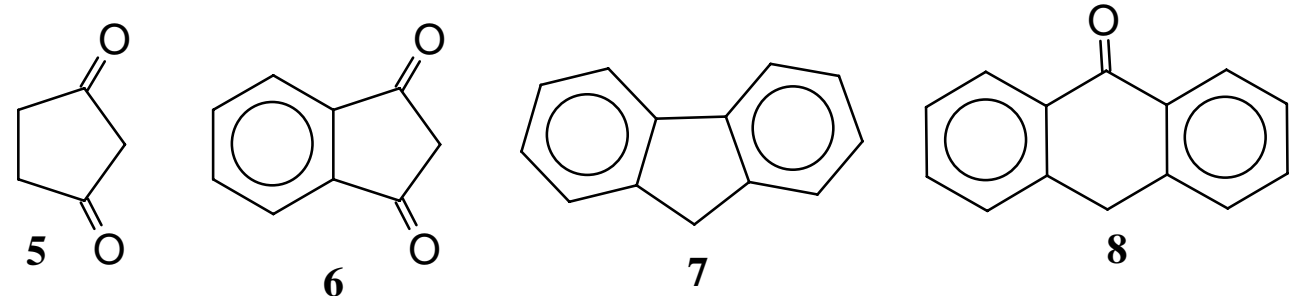

Based on this precedence, dimedone was reacted with allyl acetate in the presence of Pd catalyst, $\left[\mathrm{Pd}\left(\mathrm{PPh}_{3}\right)_{4}\right]$ in THF at RT for $1 \mathrm{~h}$ (Scheme 1) to give the diallyl dione $\mathbf{9}$. Similarly, the preparation of the other diallyl derivative $\mathbf{1 0}$ was achieved by following the above general procedure, whereas compound $\mathbf{1 1}$ was prepared by using DBU as a base during the alkylation step. ${ }^{11}$ However, compound $\mathbf{1 2}$ was initially prepared under similar conditions $\left(\mathrm{DBU} /\left[\mathrm{Pd}\left(\mathrm{PPh}_{3}\right)_{4}\right]\right)$, only as a minor product. Later on, the reaction conditions were standardized to deliver the required diallyl compound $\mathbf{1 2}$ as the sole product.

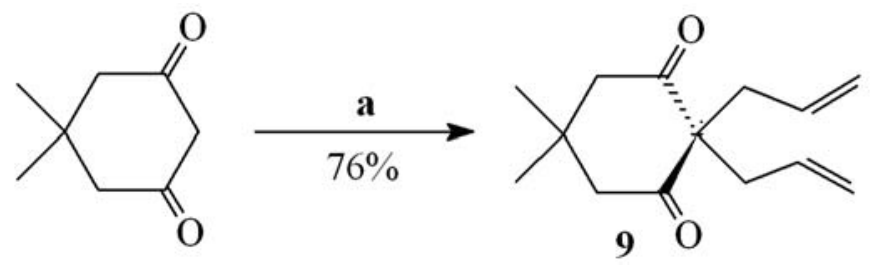

Scheme 1. a. [Pd($\left.\left(\mathrm{PPh}_{3}\right)_{4}\right]$, allyl acetate, THF, RT.

We have also found that the phase-transfer conditions $\left[\mathrm{K}_{2} \mathrm{CO}_{3}\right.$, tetrabutylammonium hydrogen sulfate (TBAHS) and $\mathrm{CH}_{3} \mathrm{CN}$ ], developed in our laboratory in connection with an amino acid project ${ }^{12}$ and also other basic conditions gave good yields of dialkylated products $\mathbf{9}$, 10 and 12. Reaction of potassium metal with fluorene 7 in dioxane at $110{ }^{\circ} \mathrm{C}$ for $5 \mathrm{~h}$ according to the reported procedure gave 9,9-diallyfluorene $\mathbf{1 3} .{ }^{13}$ In some cases 1,3-diketone derivatives were allylated using KF/celite conditions. ${ }^{14}$ The diallyl anthrone 14, was prepared by treating the anthrone 8 with allyl bromide. ${ }^{15}$

Having obtained various diallylated products in fair yield, the next task was to demonstrate the key RCM reaction. Initially the diallyl dione 9 was subjected to RCM reaction ${ }^{16-18}$ by reacting with catalytic quantities of Grubbs' catalyst 15 in $\mathrm{CH}_{2} \mathrm{Cl}_{2}$ at RT for $12 \mathrm{~h}$. At the conclusion of the reaction (TLC monitoring), the solvent was evaporated at reduced pressure and the crude product was purified by chromatography using EtOAc-Hexane (3:97) as eluent to afford the required spiro-derivative 16 (95\%, mp $95-96{ }^{\circ} \mathrm{C}$, Scheme 2$)$. 


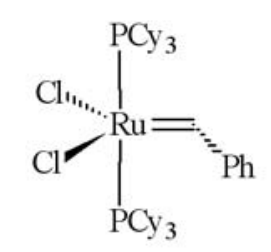

15

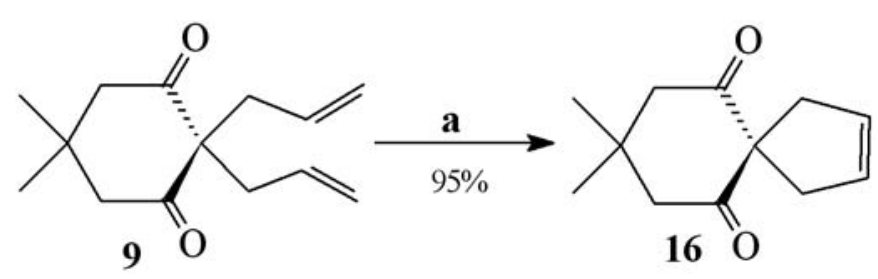

Scheme 2. a. [Ru] catalyst, $\mathrm{CH}_{2} \mathrm{Cl}_{2}$, $\mathrm{RT}$.

The structure of the spiro-compound $\mathbf{1 6}$ was established on the basis of complementary spectral data. The ${ }^{1} \mathrm{H}$ NMR spectral data of $\mathbf{1 6}$ clearly showed the disappearance of terminal olefinic protons and the appearance of cyclopentene protons [ $\delta 2.64(\mathrm{~s}, 4 \mathrm{H}), 5.54(\mathrm{~s}, 2 \mathrm{H})]$. Furthermore, a seven-line ${ }^{13} \mathrm{C}$ NMR spectrum indicated the presence of $\mathrm{C}_{2}$ symmetry in the molecule. The mass spectral data (m/z 192) further confirmed the structure of the compound 16.

Along similar lines, various spiro-systems were prepared (Table I) and fully characterized by their spectral data. Some of the RCM products deserve special mention. For example, substrates 18 and 19 constitute the CD and BCD rings of fredericamycin 1 structure. Similarly, many of the RCM products reported in Table I are potential precursors for various unknown fenestrane frames.

\section{Conclusions}

We have succeeded in developing a general and versatile method for the synthesis of several spiro-cyclic systems. The RCM method developed here offers very mild reaction conditions for the direct formation of spiro-compounds with an additional double bond for further synthetic manipulation. The flexibility of this method has been demonstrated via the synthesis of various spiro-cyclic systems and the methodology described here may find interesting applications in the synthesis of natural and non-natural products.

Table 1. Various spiro derivatives prepares by RCM reaction 


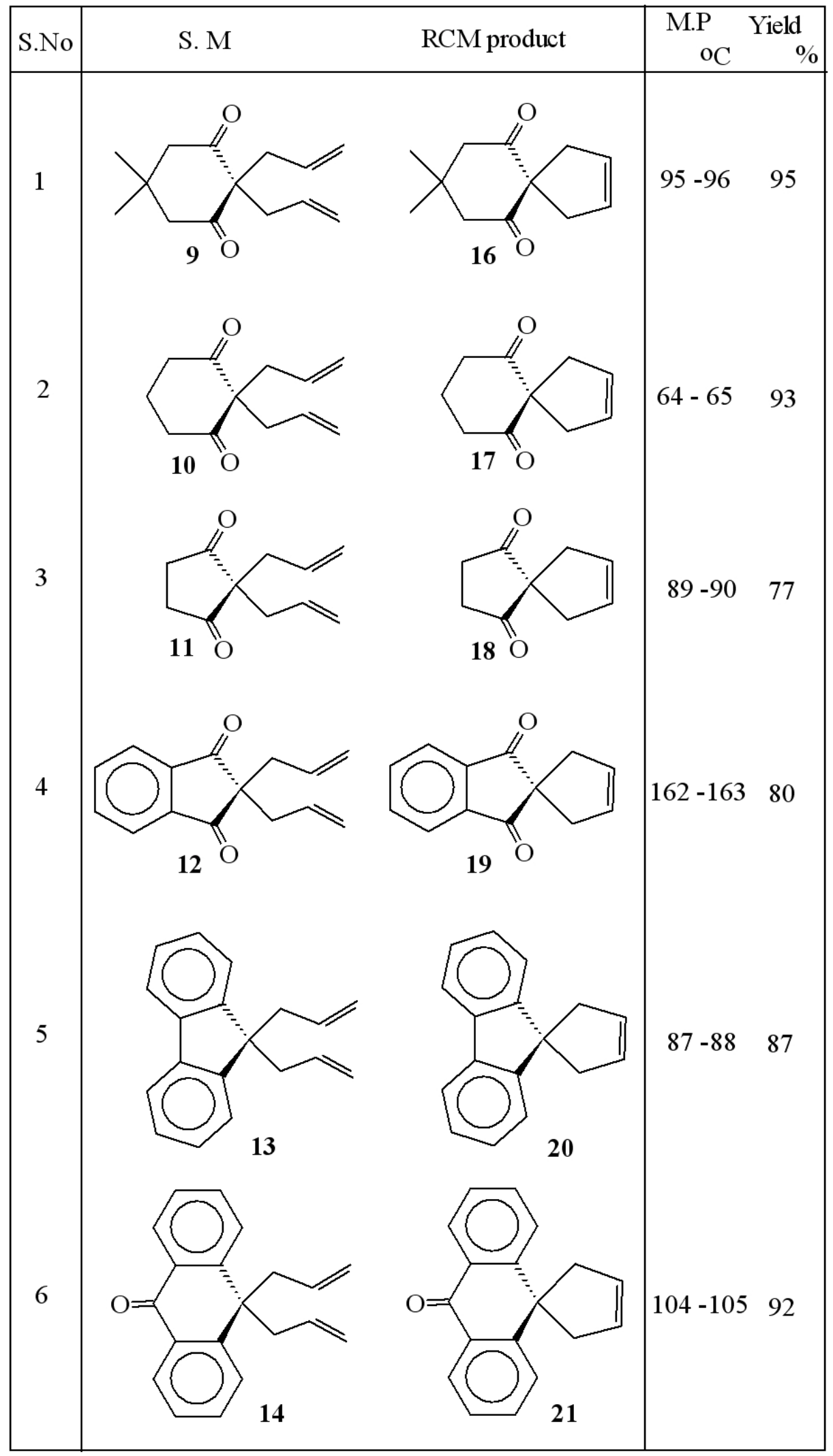




\section{Experimental Section}

General Procedures. Melting points were recorded on Labhosp or Veego melting point apparatus and are uncorrected. Boiling points refer to the bath temperatures. Room temperature (RT) refers to $\sim 35{ }^{0} \mathrm{C}$. Infrared (IR) spectra were recorded on Nicolet Impact-400 FT IR spectrometer. Solid samples were recorded in $\mathrm{KBr} / \mathrm{CHCl}_{3} / \mathrm{CCl}_{4}$ and liquid samples as their thin film between $\mathrm{NaCl}$ plates and the absorptions are reported in $\mathrm{cm}^{-1}$. Ultraviolet spectra were recorded on Shimadzu UV-2100 or UV-260 instruments. Proton Nuclear Magnetic Resonance ( ${ }^{1} \mathrm{H}$ NMR) spectra were generally recorded on EM-360 (60 MHz) or Varian VXR 300 (300 $\mathrm{MHz})$ spectrometers. Carbon Nuclear Magnetic Resonance $\left({ }^{13} \mathrm{C}\right.$ NMR) spectra were generally made in chloroform-d solvent and chemical shifts were reported in delta scale using tetramethylsilane (TMS) as the internal standard. Mass spectral measurements were carried out on GCD 1800 Hewlett-packerd GS-MS spectrometer. Elemental analysis was performed on Carlo-Ebra MOD 1106 CHN analyzer. Analytical thin-layer chromatography (TLC) were performed on $(10 \times 5 \mathrm{~cm})$ glass plates coated with Acme's silica gel G or GF 254 (containing $13 \%$ calcium sulfate as a binder). The column is usually eluted with ethyl acetate-petroleum ether $\left(60-80{ }^{\circ} \mathrm{C}\right)$ mixture. Grubbs' catalyst was purchased from Strem Chemical Co. The known compounds $\mathbf{9}, \mathbf{1 0}$ and 12 prepared in the present study by a different route are verified by ${ }^{1} \mathrm{H}$ NMR spectral data.

Preparation of 2,2-diallyl-5,5-dimethylcyclohexane-1,3-dione (9). By following KF/celite method: ${ }^{14}$ To a mixture of dimedone $(140 \mathrm{mg}, 1 \mathrm{mmol})$ and allylbromide $(0.25 \mathrm{~mL}, 3 \mathrm{mmol})$ in $\mathrm{CH}_{3} \mathrm{CN}\left(3 \mathrm{~mL}\right.$ ) was added $\mathrm{KF}$-celite $\left(590 \mathrm{mg}\right.$ ) and the reaction mixture was heated at $75^{\circ} \mathrm{C}$ for a period of $4 \mathrm{~h}$. Then, the reaction mixture was filtered off and the filtrate was concentrated at reduced pressure to give the crude product. It was further purified on a silica gel column by eluting with ethyl acetate and petroleum ether mixture (1:19) to give the diallyl product 9 (102 mg, 46\%).

Preparation of 2,2-diallylcyclohexane-1,3-dione (10). By following KF/celite method: ${ }^{14}$ To a mixture of 1,3-cyclohexanedione (112 mg, $1 \mathrm{mmol})$ and allylbromide $(0.25 \mathrm{~mL}, 3 \mathrm{mmol})$ in $\mathrm{CH}_{3} \mathrm{CN}(3 \mathrm{ml})$ was added KF-celite $(590 \mathrm{mg})$ and the mixture was heated at $75{ }^{\circ} \mathrm{C}$ for a period of $6 \mathrm{~h}$. Then, the reaction mixture was filtered off and the filtrate was concentrated to give the crude product which was purified on a silica gel column by eluting with ethyl acetate and petroleum ether mixture (3:97) to give the diallyl product 10 (96 mg, 50\%).

Preparation of 2,2-diallylindane-1,3-dione (12). By following KF/celite method: ${ }^{14}$ To a mixture of indane-1,3-dione 6 (438 mg, $3 \mathrm{mmol}$ ) and allylbromide $\left(0.5 \mathrm{~mL}, 6 \mathrm{mmol}\right.$ ) in $\mathrm{CH}_{3} \mathrm{CN}$ $(8 \mathrm{~mL})$ was added KF-celite $(1.01 \mathrm{~g})$ and the mixture was heated at $75{ }^{\circ} \mathrm{C}$ for a period of $20 \mathrm{~h}$. Then, the reaction mixture was filtered off and the filtrate was concentrated to give the crude 
product. Purification on a silica gel column by eluting with ethyl acetate and petroleum ether mixture (4:96) afforded the diallyl product 12 (353 mg, 52\%).

By following PTC method: ${ }^{12}$ To a mixture of indane-1,3-dione 6 (37 mg, $0.25 \mathrm{mmol}$ ) and allylbromide (0.02 mL, $0.25 \mathrm{mmol})$ in $\mathrm{CH}_{3} \mathrm{CN}(8 \mathrm{~mL})$ was added $\mathrm{K}_{2} \mathrm{CO}_{3}(35 \mathrm{mg}, 0.25 \mathrm{mmol}$ ) and TBAHS (9 mg, $0.025 \mathrm{mmol}$ ) and the mixture was stirred for a period of $8 \mathrm{~h}$. Then, the reaction mixture was filtered off and the filtrate was concentrated to give the crude product which was purified on a silica gel column by eluting with ethyl acetate and petroleum ether mixture (4:96) to afford the diallyl product 12 (30 mg, 53\%).

By following benzyltriethylammonium chloride (BETAC) method: ${ }^{15}$ To a mixture of indane1,3-dione 6 (73 mg, $0.5 \mathrm{mmol}$ ) and allylbromide $(0.04 \mathrm{~mL}, 0.5 \mathrm{mmol})$ in $\mathrm{CH}_{2} \mathrm{Cl}_{2}(3 \mathrm{~mL})$ was added a solution of BTEAC ( $25 \mathrm{mg}, 0.1 \mathrm{mmol})$ in $30 \%$ aq. $\mathrm{NaOH}(2.5 \mathrm{~mL})$ and the mixture was stirred for a period of $2 \mathrm{~h}$. Then, the reaction mixture was diluted with water $(15 \mathrm{~mL})$ and extracted with $\mathrm{CH}_{2} \mathrm{Cl}_{2}(3 \times 25 \mathrm{~mL})$. The combined organic extract was washed with $2 \mathrm{~N} \mathrm{HCl}(5$ $\mathrm{mL}), 5 \%$ aq. $\mathrm{NaHCO}_{3}(5 \mathrm{~mL})$ and brine $(5 \mathrm{~mL})$ and dried over $\mathrm{MgSO}_{4}$. The solvent was removed in vacuo and the crude product was recrystallised from $\mathrm{CHCl}_{3} /$ petroleum ether mixture, to deliver the diallyl compound 12 (62 mg, 54\%).

General procedure for RCM reaction. To a solution of diallyl compound 9 (25 mg, 0.114 mmol) in dry $\mathrm{CH}_{2} \mathrm{Cl}_{2}(4 \mathrm{~mL})$ was added Grubbs' catalyst (5 mg, $5.4 \mathrm{~mol} \%$ ) and the reaction mixture was stirred at RT for $12 \mathrm{~h}$ under $\mathrm{N}_{2}$. Then, the solvent was removed on a rotavapor and the resulting crude product was charged on a silica gel column. Elution of the column with ethyl acetate and petroleum ether mixture (3:97) gave the RCM product $\mathbf{1 6}$ as a colorless crystals (21 mg, 95\%); $\mathrm{R}_{\mathrm{f}}$ : 0.72, 50\%, ethyl acetate-petroleum ether, mp 95-96 ${ }^{\circ} \mathrm{C}$; IR ( $\left.\mathrm{KBr}\right) 1722(\mathrm{C}=\mathrm{O})$, $1696 \mathrm{~cm}^{-1} ;{ }^{1} \mathrm{H}$ NMR (300 MHz, $\left.\mathrm{CDCl}_{3}\right) \delta=1.00$ (s, 6H), 2.64 (s, 4H), $2.86(\mathrm{~s}, 4 \mathrm{H}), 5.54(\mathrm{~s}, 2 \mathrm{H})$; ${ }^{13} \mathrm{C}$ NMR (75.43 MHz, $\mathrm{CDCl}_{3}$ ) $\delta=28.4,30.3$, 38.9, 51.4, 69.7, 127.1, 205.9; Mass m/z 192 $\left(\mathrm{M}^{+}\right)$; Analysis: found $\mathrm{C}, 74.48, \mathrm{H}, 8.83 . \mathrm{C}_{12} \mathrm{H}_{16} \mathrm{O}_{2}$ requires $\mathrm{C}, 74.97, \mathrm{H}, 8.39 \%$.

Preparation of spiro 1,3-dione (17). To a solution of diallyl compound 10 (50 mg, $0.260 \mathrm{mmol}$ ) in dry $\mathrm{CH}_{2} \mathrm{Cl}_{2}(3 \mathrm{~mL})$ was added Grubbs' catalyst $(11 \mathrm{mg}, 5.15 \mathrm{~mol} \%)$ was stirred at RT for $26 \mathrm{~h}$ under $\mathrm{N}_{2}$ according to the general procedure. Then, the solvent was removed on a rotavapor and the resulting crude product was charged on a silica gel column. Elution of the column with ethyl acetate and petroleum-ether mixture (1:9) gave the RCM product $\mathbf{1 7}$ as a colorless crystals (40 mg, 93\%); $\mathrm{R}_{\mathrm{f}}$ : 0.28, 20\%, ethyl acetate-petroleum ether; mp 64-65 ${ }^{\circ} \mathrm{C}$; IR ( $\left.\mathrm{KBr}\right) 1729(\mathrm{C}=\mathrm{O})$, $1703 \mathrm{~cm}^{-1} ;{ }^{1} \mathrm{H}$ NMR $\left(300 \mathrm{MHz}, \mathrm{CDCl}_{3}\right) \delta=1.99(\mathrm{q}, J=6.7 \mathrm{~Hz}, 2 \mathrm{H}), 2.71(\mathrm{t}, J=6.7 \mathrm{~Hz}, 4 \mathrm{H})$, 2.87 (s, 4H), $5.54(\mathrm{~s}, 2 \mathrm{H}) ;{ }^{13} \mathrm{C}$ NMR $\left(75.43 \mathrm{MHz}, \mathrm{CDCl}_{3}\right) \delta=17.5,37.6,39.1,70.9,127.1$, 207.1; Mass m/z $164\left(\mathrm{M}^{+}\right)$; Analysis: found $\mathrm{C}, 73.22, \mathrm{H}, 7.61 . \mathrm{C}_{10} \mathrm{H}_{12} \mathrm{O}_{2}$ requires $\mathrm{C}, 73.15, \mathrm{H}$, 7.36\%.

Preparation of spiro 1,3-dione (18). To a solution of diallyl compound 11 (300 mg, $1.68 \mathrm{mmol}$ ) in dry $\mathrm{CH}_{2} \mathrm{Cl}_{2}(15 \mathrm{~mL})$ was added Grubbs' catalyst $(83 \mathrm{mg}, 6 \mathrm{~mol} \%)$ and the reaction mixture was stirred at RT for $24 \mathrm{~h}$ under $\mathrm{N}_{2}$ according to the general procedure. Then, the solvent was removed on a rotavapor and the resulting crude product was charged on a silica gel column. Elution of the column with ethyl acetate and petroleum ether mixture (2:98) gave the RCM 
product 18 as a colorless crystals (195 mg, 77\%); $\mathrm{R}_{\mathrm{f}}$ : 0.48, 20\%, ethyl acetate-petroleum ether; mp 89-90 ${ }^{\circ} \mathrm{C}$; IR (KBr) $1712(\mathrm{C}=\mathrm{O}) \mathrm{cm}^{-1}$; ${ }^{1} \mathrm{H}$ NMR $\left(300 \mathrm{MHz}, \mathrm{CDCl}_{3}\right) \delta=2.66$ (s, 4H), 2.83 (s, $4 \mathrm{H}), 5.61$ (s, 2H); ${ }^{13} \mathrm{C}$ NMR $\left(75.43 \mathrm{MHz}, \mathrm{CDCl}_{3}\right) \delta=34.8,41.0,61.0,127.4$, 213.4; Mass m/z $150\left(\mathrm{M}^{+}\right)$; Analysis: found $\mathrm{C}, 72.64, \mathrm{H}, 6.90 . \mathrm{C}_{9} \mathrm{H}_{10} \mathrm{O}_{2}$ requires $\mathrm{C}, 71.98, \mathrm{H}, 6.71 \%$.

Preparation of spiro 1,3-dione (19). To a solution of diallyl compound 12 (50 mg, $0.22 \mathrm{mmol}$ ) in dry toluene $(5 \mathrm{~mL})$ was added Grubbs' catalyst (13 mg, $7.2 \mathrm{~mol} \%$ ) and the reaction mixture was stirred and heated the mixture at $110{ }^{\circ} \mathrm{C}$ for $30 \mathrm{~h}$ under $\mathrm{N}_{2}$ according to the general procedure. Then, the toluene was removed at reduced pressure and the resulting crude product was charged on a silica gel column. Elution of the column with ethyl acetate and petroleum-ether mixture (1:99) gave the RCM product 19 (35 $\mathrm{mg}, 80 \%$ ) as a colorless crystals; $\mathrm{R}_{\mathrm{f}}$ : $0.67,5 \%$, ethyl acetate-petroleum ether; mp 162-163 ${ }^{\circ} \mathrm{C}$; IR $(\mathrm{KBr}) 1743(\mathrm{C}=\mathrm{O}) \mathrm{cm}^{-1}$; UV $\left(\mathrm{CH}_{3} \mathrm{CN}\right) \lambda_{\max }(\epsilon$ $\mathrm{M}^{-1} \mathrm{~cm}^{-1}$ ) 246 (6448), 222 (25396) nm; ${ }^{1} \mathrm{H}$ NMR (300 MHz, $\left.\mathrm{CDCl}_{3}\right) \delta=2.78$ (s, 4H), 5.75 (s, $2 \mathrm{H}), 7.86$ (q, $J=3.3 \mathrm{~Hz}, 2 \mathrm{H}), 8.01(\mathrm{q}, J=3.3 \mathrm{~Hz}, 2 \mathrm{H}) ;{ }^{13} \mathrm{C} \mathrm{NMR}\left(75.43 \mathrm{MHz}, \mathrm{CDCl}_{3}\right) \delta=41.7$, 57.6, 123.6, 128.3, 135.5, 141.9, 203.0; Mass m/z $198\left(\mathrm{M}^{+}\right)$; Analysis: found C, 79.67, H, 4.98. $\mathrm{C}_{13} \mathrm{H}_{10} \mathrm{O}_{2}$ requires $\mathrm{C}, 78.77, \mathrm{H}, 5.09 \%$.

Preparation of compound (20). To a solution of diallyl compound 13 (130 mg, $0.53 \mathrm{mmol})$ in dry toluene ( $8 \mathrm{~mL}$ ) was added Grubbs' catalyst (22 $\mathrm{mg}, 5 \mathrm{~mol} \%)$ and the reaction mixture was heated at $110{ }^{\circ} \mathrm{C}$ for $3 \mathrm{~h}$ under $\mathrm{N}_{2}$ according to the general procedure. Then, the solvent was evaporated on a rotavapor and the resulting crude product was charged on a silica gel column. Elution of the column with petroleum ether gave the RCM product $\mathbf{2 0}$ as a white solid (100 $\mathrm{mg}$, 87\%); $\mathrm{R}_{\mathrm{f}}$ : 0.94, $1 \%$, ethyl acetate-petroleum ether; mp 87-88 ${ }^{\circ} \mathrm{C}$; IR (KBr) $1444 \mathrm{~cm}^{-1}$; UV $\left(\mathrm{CH}_{3} \mathrm{CN}\right) \lambda_{\max }\left(\in \mathrm{M}^{-1} \mathrm{~cm}^{-1}\right) 265$ (18426), 206 (29485) nm; ${ }^{1} \mathrm{H}$ NMR (300 MHz, $\left.\mathrm{CDCl}_{3}\right) \delta=2.88$ (s, 4H), 5.99 (s, 2H), 7.24-7.35 (m, 4H), 7.48-7.51 (m, 2H), 7.67-7.70 (m, 2H); ${ }^{13} \mathrm{C}$ NMR $(75.43$ $\left.\mathrm{MHz}, \mathrm{CDCl}_{3}\right) \delta=46.2,55.4,119.7,122.4,127.0,127.7,130.3,139.4,154.3$; Mass: m/z 218 $\left(\mathrm{M}^{+}\right)$; Analysis: found C, 93.13, $\mathrm{H}, 5.99 . \mathrm{C}_{17} \mathrm{H}_{14}$ requires $\mathrm{C}$, 93.54, $\mathrm{H}, 6.46 \%$.

Preparation of spiro compound (21). To a solution of diallyl compound 14 (91 mg, $0.33 \mathrm{mmol}$ ) in dry $\mathrm{CH}_{2} \mathrm{Cl}_{2}(4 \mathrm{~mL})$ was added Grubbs' catalyst (12 mg, $4.4 \mathrm{~mol} \%$ ) and the reaction mixture was stirred at RT for $2 \mathrm{~h}$ under $\mathrm{N}_{2}$ according to the general procedure. Then, the solvent was removed on a rotavapor and the resulting crude product was charged on a silica gel column. Elution of the column with ethyl acetate-petroleum ether mixture (5:95) gave the RCM product 21 as a colorless crystals (75 mg, 92\%); $\mathrm{R}_{\mathrm{f}}$ : 0.46, 5\%, ethyl acetate-petroleum ether; mp 104-105 ${ }^{\circ} \mathrm{C}$; IR (KBr) $1653(\mathrm{C}=\mathrm{O}), 1598 \mathrm{~cm}^{-1}$; UV ( $\left.\mathrm{CH}_{3} \mathrm{CN}\right) \lambda_{\max }\left(\in \mathrm{M}^{-1} \mathrm{~cm}^{-1}\right) 267$ (20041), 207 (27823) nm; ${ }^{1} \mathrm{H}$ NMR (300 MHz, CDCl $) \delta=3.18$ (s, 4H), 6.04 (s, 2H), 7.50 (hep, $J=7.0 \mathrm{~Hz}, 6 \mathrm{H}$ ), 8.31 (d, $J=7.0 \mathrm{~Hz}, 2 \mathrm{H}) ;{ }^{13} \mathrm{C}$ NMR $\left(50 \mathrm{MHz}, \mathrm{CDCl}_{3}\right) \delta=45.7,56.0,126.3,126.6,129.3,130.1$, 134.2, 153.0; Mass m/z $246\left(\mathrm{M}^{+}\right)$; Analysis: found C, 87.13, $\mathrm{H}$, 5.99. $\mathrm{C}_{18} \mathrm{H}_{14} \mathrm{O}$ requires $\mathrm{C}$, 87.77, H, $5.73 \%$.

\section{Acknowledgements}


We gratefully acknowledge the DST, New Delhi for the financial support and RSIC-Mumbai for recording the NMR and mass spectral data. EM wish to thank CSIR, New Delhi for the scholarship (SRF).

\section{References and Notes}

1. For selected examples related to fredericamycin synthesis see. (a) Kelly, T. R.; Ohashi, N. $J$. Am. Chem. Soc. 1986, 108, 7100; Mehta, G.; Subrahmanyam, D. Tetrahedron 1987, $28,479$. (b) Rama Rao, A. V.; Singh, A. K.; Venkateswara Rao, B.; Reddy, M. Tetrahedron Lett. 1993, 34, 2665. (c) Kita, Y.; Higuchi, K.; Yoshida, Y.; Iio, K.; Kitagaki, S.; Shuji, A.; Fujioka, H. Angew. Chem. Int. Ed. Engl. 1999, 38, 683. (d) Kita, Y.; Higuchi, K.; Yoshida, Y.; Iio, K.; Kitagaki, S.; Ueda, K.; Shuji, A.; Fujioka, H. J. Am. Chem. Soc. 2001, 123, 3214.

2. (a) Marshall, J. A. Progress in Chemistry of Natural Products 1974, 31, 283. (b) Heathcock, C. K.; Graham, S. L.; Pirrung Palvac, F.; White, C. T. Total Synthesis of Natural Products, Ed. ApSimon, J. Vol. 5, NewYork: John Wiely, (1983); pp 264-314.

3. (a) Mehta, G.; Srikrishna, A. Chem Rev. 1997, 97, 671. (b) Singh, V. K.; Thomas, B. Tetrahedron 1998, 54, 3647.

4. MacKinnon, S. L.; Bensimon, C.; Arnason, J. T.; Sanchez-Vindas, P. E.; Durst, T. J. Org. Chem. 1997, 62, 840.

5. Kocovsky, P.; Turecek, F.; Hajicek, J. Synthesis of Natural Products: Problems of Selectivity Vol. 1: Chapter 4, Boca Ratan: CRC Press, 1986, 89.

6. (a) Thommen, M.; Keese, R. Synlett, 1997, 231. (b) Kuck, D. Topics Curr Chem 1998, 196, 168.

7. Fitjer, L.; Klages, U.; Wehle, D.; Giersig, M.; Schormann, N.; Clegg, W.; Stephensen, D. S.; Binsch, G. Tetrahedron 1988, 46, 416.

8. For reviews on the synthesis of spiro compounds see: (a) Krapcho, A. P. Synthesis 1978, 77. (b) Martin, S. F. Tetrahedron, 1980, 36, 419. (c) Sannigrahi, M. Tetrahedron 1999, 55, 9007. For preliminary communication of our work in this area please see: Kotha, S.; Manivannan, E. Ganesh, T.; Sreenivasachary, N.; Deb, A. Synlett 1999, 1618.

9. Lapintskaya, M. A.; Pivnitsky, K. K. Zhur. Org. Khim. (Russ) 1991, 2560; Giambastiani, G.; Poli, G. J. Org. Chem. 1998, 63, 9608.

10. Ferroud, F.; Genet, J. P.; Muzart, J. Tetrahedron Lett. 1984, 25, 4379.

11. Shwartz, C. E.; Curran, D. J. Am. Chem. Soc. 1990, 112, 9272.

12. (a) Kotha, S.; Brahmachary, E. Bioorg. Med. Chem. Lett. 1998, 8, 2719. (b) Kotha, S.; Brahmachary, E. Tetrahedron Lett. 1997, 38, 3561. (c) Kotha, S.; Brahmachary, E. J. Org. Chem. 2000, 65, 1359.

13. Scherf, G. W. H.; Brown, R. K. Can. J. Chem. 1960, 38, 697.

14. (a) Block, R.; Orvane, P. Synth. Commun. 1981, 11, 913. (b) Kuck, D. Chem. Ber. 1994, 127, 407. 
15. Majumdar, K. C.; Chattopadhyay, S. K.; Khan, A. T. Synthesis 1988, 552.

16. For selected reviews on olefin metathesis reaction see: (a) Kotha, S.; Sreenivasachary, N. Indian J. Chem. 2001, 763. (b) Hoyeda, A. M.; Schock, R. R. Chem. Eur. J. 2001, 945. (c) Trnka, T. M.; Grubbs, R. H. Acc. Chem. Res. 2001, 34, 18. (d) Maier, M. E. Angew. Chem. Int. Ed. Engl. 2000, 39, 2073. (e) Roy, R.; Das, S. K. J. Chem. Soc. Chem. Commun. 2000, 503.

17. For selected examples of spiro-cyclics by metathesis reaction see: (a) Limieux, R. M.; Devine, P. N.; Mechelke, M. F.; Meyers, A. I. J. Org. Chem. 1999, 64, 3585. (b) Hammer, K.; Undheim, K. Tetrahedron, 1997, 53, 2309. (c) Bassindale, M. J.; Hamley, P.; Leitner, A.; Harrity, J. P. A. Tetrahedron Lett. 1999, 40, 3247. (d) Bassindale, M. J.; Edwards, A. S.; Hamely, P.; Adams, H.; Harrity, J. P. J. Chem. Soc. Chem. Commun. 2000, 1035. (e) Maity, B. C.; Swamy, V. M.; Sarkar, A. Tetrahedron Lett. 2001, 42 4373. (f) Gurjar, M. K.; Ravindranath, S. V.; Karmakar, S. Chem. Commun. 2001, 241. (g) Srikrishna, A.; Srinivasa Rao, M.; Gharpure, S. J.; Chandrasekhar Babu, N. Synlett 2001, 1986. (h) Sabita, G.; Srinivas Reddy, Ch.; Satheesh Babu, R.; Yadav, J. S. Synlett 2001, 1787.

18. For details of our earlier work dealing with olefin metathesis reaction see: (a) Kotha, S.; Sreenivasachary, N.; Mohanraja, K.; Durani, S. Bioorg Med. Chem. Lett. 2001, 11, 1421. (b) Kotha, S.; Sreenivasachary, N.; Brahmachary, E. Eur. J. Org. Chem. 2001, 787. (c) Kotha, S.; Sreenivasachary, N. Eur. J. Org. Chem. 2001, 3375. (d) Kotha, S.; Sreenivasachary, N. J. Chem. Soc. Chem. Commun. 2000, 503. (e) Kotha, S.; Halder, S.; Brahmachary, E.; Ganesh, T. Synlett 2000, 853. (f) Kotha, S.; Sreenivasachary, N. Bioorg. Med. Chem. Lett. 1998, 8, 257. (g) Kotha, S.; Sreenivasachary, N.; Brahmachary, E.; Tetrahedron Lett. 1998, 39, 2805. 